УДК 615.254.1

\title{
ИЗУЧЕНИЕ АНТИМИКРОБНОГО ДЕЙСТВИЯ АРБУТИНА И ГИДРОХИНОНА В ОТНОШЕНИИ НЕКОТОРЫХ ПРЕДСТАВИТЕЛЕЙ ГРАМОТРИЦАТЕЛЬНОЙ ФЛОРЫ
}

\author{
(C) Н.Л. Волобой", Л.Ю. Бутакова, И.В. Смирнов
}

\author{
Алтайский государственный медицинский университет, пр. Ленина, 40, \\ Барнаул, (Россия), e-mail: voloboyn@gmail.com
}

Антимикробные свойства многих растений, применяемых в урологической практике, часто связывают с расщеплением арбутина до гидрохинона, который собственно и является антисептиком. Однако, несмотря на сложившееся представление о действии арбутинсодержащих растений, экспериментально до сих пор не установлено, арбутину или гидрохинону принадлежит ведущая роль в осуществлении антимикробного эффекта.

Проведено сравнение противомикробного действия арбутина и гидрохинона в отношении некоторых грамотрицательных микроорганизмов.

Выяснено, что действие арбутина на микроорганизмы реализуется при его гидролизе и в зависимости от условий может быть антибактериальным за счет выделения гидрохинона или способствовать росту бактерий за счет выделения глюкозы. Гидрохинон оказывает выраженное антибактериальное действие в отношении всех изученных штаммов грамотрицательных микроорганизмов.

Ключевые слова: арбутин, гидрохинон, микроорганизмы, гидролиз, антибактериальное действие.

\section{Введение}

Препараты растительного происхождения все чаще используются в качестве лечебных средств, назначаемых нефрологами и урологами. Связано это преимущественно с широким распространением лекарственно устойчивых форм бактерий и изменением иммунологического статуса организма. При назначении лекарственных препаратов с антибактериальным эффектом следует учитывать высокую активность действующих веществ и широкий спектр их противомикробного действия и, помимо этого, относительную безвредность для человека в концентрациях, достаточных для подавления роста и размножения микроорганизмов. Такое комплексное антимикробное действие характерно для растений. Наиболее популярными в урологической практике являются арбутинсодержащие виды растительного сырья: листья толокнянки, брусники, зимолюбки и др. Известно, что эти растения обладают достаточно выраженными мочегонными, противовоспалительными, антиоксидантными, противомикробными свойствами [1-3]. Антимикробные свойства данных растений часто связывают с гидролизом арбутина до гидрохинона [4]. Однако, несмотря на сложившееся представление о действии арбутинсодержащих растений, экспериментально до сих пор не установлено, какому из веществ - арбутину или гидрохинону - принадлежит ведущая роль в осуществлении антимикробного эффекта.

Таким образом, целью настоящей работы явилось сравнение противомикробного действия арбутина и гидрохинона в отношении некоторых грамотрицательных микроорганизмов.

Волобой Нина Леонидовна - преподаватель кафедры фармакогнозии и ботаники, тел.: (3852) 66-99-27, e-mail: voloboyn@gmail.com

Бутакова Любовь Юрьевна - заведующая кафедрой микробиологии с вирусологией, доцент, тел.: (3852) 26-07-80, e-mail: lbutakova@gmail.com Смирнов Иван Владимирович - заведующий кафедрой фармакогнозии и ботаники, доцент, тел.: (3852) 66-99-27, e-mail: ivan.vl.smirnov@ gmail.com

\section{Экспериментальная часть}

Антимикробную активность изучали в отношении музейных стандартных штаммов (E. coli 163, Proteus mirabilis, Klebsiela pneumoniae) и клинических штаммов (E. coli 137, выделенная от больного хроническим пиелонефритом, и E. coli 379, выделенная от больного хроническим циститом).

\footnotetext{
*Автор, с которым следует вести переписку.
} 
В качестве среды использовали мясо-пептонный бульон. В пробирках, содержащих по 5 мл среды, растворяли стандартный образец арбутина в количестве, необходимом для создания концентраций 37,70 , 100 ммоль/л, и химически чистый гидрохинон в тех же концентрациях. Далее в эти же пробирки стерильной пипеткой вносили по 0,2 мл культуры по стандарту мутности Мак Фарланда 1,0 и термостатировали при температуре $35^{\circ} \mathrm{C}$. Время экспозиции составляло 10 ч с измерением оптической плотности растворов каждые 2 ч, а затем через сутки термостатирования. Оптическую плотность измеряли на приборе Densi La Meter. В качестве контроля использовали 5 мл среды, содержащей 0,2 мл соответствующей культуры. При растворении гидрохинона в бульоне происходило потемнение среды. Поэтому для гидрохинона в качестве контроля использовали его растворы в концентрации 37, 70 и 100 ммоль/л. Результаты исследования приведены в таблицах $1,2$.

\section{Обсуждение результатов}

Из таблицы 1 видно, что арбутин в концентрации 100 ммоль/л в некоторой степени задерживает размножение E. coli 163. Начиная с четвертого часа экспозиции размножение данного штамма кишечной палочки уменьшалось по сравнению с контролем на $30 \%$, к шестому часу эта разница снизилась до $17 \%$ и оставалась такой до конца эксперимента. Также наблюдалась тенденция к подавлению размножения Pr. mirabilis во всех трех концентрациях арбутина, однако наиболее выраженной она была в концентрации вещества 100 ммоль/л. Задержка роста микроорганизма арбутином в концентрации 100 ммоль/л наблюдалась начиная с четвертого часа и составляла на тот момент $29 \%$ по отношению к контролю, с шестого часа и до окончания наблюдения эта разница составляла $20 \%$. На рост Klebsiela pneumoniae арбутин не оказывал никакого действия в течение 10 ч, однако к концу суток было отмечено некоторое подращивание бактерий в среде с арбутином (на 17\%). На размножение E. coli 137, выделенной от больного хроническим пиелонефритом, растворы арбутина также не влияли.

А штамм E. coli 379, выделенный от больного хроническим циститом, в среде с арбутином активно размножался с выделением пузырьков газа и обильной пеной при взбалтывании.

При растворении гидрохинона в среде наблюдалось ее потемнение, что, соответственно, вызывает увеличение показаний оптической плотности растворов. Поэтому для гидрохинона были взяты отдельные контроли, в качестве которых использовали гидрохинон, растворенный в среде в тех же концентрациях, что и в опытных пробирках. Следует отметить, что в процессе инкубирования растворы гидрохинона как в контрольных, так и в опытных пробирках, становились с течением времени все более темными. Повидимому, это связано с окислением гидрохинона в процессе термостатирования под действием температуры и кислорода воздуха.

Таблица 1. Влияние арбутина на размножение микроорганизмов

\begin{tabular}{l|c|c|c|c|c|c|c|c}
\hline \multirow{2}{*}{ Культура } & \multirow{2}{*}{$\begin{array}{c}\text { Концентрация } \\
\text { арбутина, ммоль/л }\end{array}$} & \multicolumn{9}{|c}{ Время, ч } & Начало & 2 & 4 & 6 & 8 & 10 & 24 \\
\hline E. coli 163 & 37 & 0,6 & 0,7 & 2,0 & 4,4 & 5,1 & 5,3 & 6,5 \\
& 70 & 0,6 & 0,7 & 2,0 & 4,3 & 4,9 & 5,1 & 6,2 \\
& 100 & 0,6 & 0,7 & 1,7 & 3,9 & 4,5 & 4,7 & 5,4 \\
& Контроль & 0,6 & 0,7 & 2,4 & 4,8 & 5,3 & 5,6 & 6,5 \\
\hline Proteus mirabilis & 37 & 0,6 & 0,7 & 2,5 & 4 & 4,2 & 4,4 & 5,2 \\
& 70 & 0,6 & 0,7 & 2,0 & 3,7 & 4,0 & 4,0 & 4,9 \\
& 100 & 0,6 & 0,7 & 2,0 & 3,4 & 3,7 & 3,7 & 4,4 \\
& Контроль & 0,6 & 0,8 & 2,8 & 4,3 & 4,6 & 4,6 & 5,5 \\
\hline Klebsiela & 37 & 0,6 & 0,7 & 1,6 & 3,2 & 3,4 & 3,5 & 4,9 \\
& 70 & 0,6 & 0,7 & 1,6 & 3,1 & 3,5 & 3,6 & 5,3 \\
& 100 & 0,6 & 0,7 & 1,4 & 2,9 & 3,3 & 3,3 & 5,3 \\
& Контроль & 0,6 & 0,7 & 1,7 & 3,2 & 3,2 & 3,4 & 4,4 \\
\hline E. coli 137 & 37 & 0,6 & 0,6 & 1,2 & 1,8 & 2,0 & 2,1 & 2,9 \\
& 70 & 0,6 & 0,7 & 1,1 & 1,9 & 2,0 & 2,2 & 3,1 \\
& 100 & 0,6 & 0,7 & 1,1 & 1,8 & 1,9 & 2,1 & 2,8 \\
& Контроль & 0,6 & 0,7 & 1,3 & 1,8 & 2,0 & 2,2 & 3,1 \\
\hline E. coli 379 & 37 & 0,6 & 0,7 & 0,8 & 2,9 & 5,0 & 5,8 & 7,0 \\
& 70 & 0,6 & 0,6 & 0,8 & 2,6 & 4,8 & 5,7 & 7,1 \\
& 100 & 0,6 & 0,6 & 0,8 & 2,4 & 4,8 & 5,7 & 7,1 \\
& Контроль & 0,6 & 0,7 & 0,8 & 1,6 & 2,0 & 2,2 & 3,7 \\
\hline
\end{tabular}


Таблица 2. Влияние гидрохинона на размножение микроорганизмов

\begin{tabular}{|c|c|c|c|c|c|c|c|c|}
\hline \multirow[t]{2}{*}{ Культура } & \multirow{2}{*}{$\begin{array}{l}\text { Концентрация гид- } \\
\text { рохинона, ммоль/л }\end{array}$} & \multicolumn{7}{|c|}{ Время, ч } \\
\hline & & Начало & 2 & 4 & 6 & 8 & 10 & 24 \\
\hline \multirow[t]{6}{*}{ E. coli 163} & 37 & 1,1 & 1,3 & 1,4 & 1,6 & 1,8 & 2,0 & 3,7 \\
\hline & Контроль & 1,1 & 1,2 & 1,4 & 1,5 & 1,7 & 1,8 & 3,3 \\
\hline & 70 & 1,4 & 1,6 & 1,8 & 2,0 & 2,2 & 2,4 & 4,3 \\
\hline & Контроль & 1,4 & 1,6 & 1,7 & 1,9 & 2,1 & 2,3 & 3,6 \\
\hline & 100 & 1,5 & 1,7 & 1,9 & 2,1 & 2,4 & 2,6 & 4,5 \\
\hline & Контроль & 1,4 & 1,6 & 1,8 & 2,0 & 2,2 & 2,4 & 3,9 \\
\hline \multirow[t]{6}{*}{ Proteus mirabilis } & 37 & 1,2 & 1,4 & 1,6 & 1,7 & 1,9 & 2,0 & 5,1 \\
\hline & Контроль & 1,1 & 1,3 & 1,4 & 1,6 & 1,8 & 1,9 & 3,3 \\
\hline & 70 & 1,5 & 1,7 & 1,8 & 2,1 & 2,2 & 2,4 & 3,6 \\
\hline & Контроль & 1,4 & 1,6 & 1,8 & 2,0 & 2,2 & 2,4 & 3,7 \\
\hline & 100 & 1,7 & 1,9 & 2,1 & 2,3 & 2,5 & 2,7 & 3,7 \\
\hline & Контроль & 1,6 & 1,8 & 2,1 & 2,4 & 2,6 & 2,8 & 3,8 \\
\hline \multirow[t]{6}{*}{ Klebsiela } & 37 & 1,2 & 1,4 & 1,5 & 1,7 & 1,8 & 2,0 & 5,7 \\
\hline & Контроль & 1,2 & 1,4 & 1,5 & 1,7 & 1,8 & 2,1 & 3,3 \\
\hline & 70 & 1,6 & 1,8 & 1,9 & 2,2 & 2,3 & 2,6 & 5,8 \\
\hline & Контроль & 1,3 & 1,4 & 1,6 & 1,9 & 2,1 & 2,3 & 3,6 \\
\hline & 100 & 1,7 & 1,9 & 2,2 & 2,4 & 2,7 & 2,9 & 4,5 \\
\hline & Контроль & 1,7 & 1,9 & 2,1 & 2,4 & 2,6 & 2,8 & 4,0 \\
\hline \multirow[t]{6}{*}{ E. coli 137} & 37 & 1,5 & 1,7 & 2.0 & 2.3 & 2.5 & 3,0 & 4.3 \\
\hline & Контроль & 1,2 & 1,4 & 1,6 & 1,8 & 2.1 & 2,3 & 3,4 \\
\hline & 70 & 1,4 & 1,7 & 2.0 & 2,3 & 2,7 & 2,9 & 4.2 \\
\hline & Контроль & 1,2 & 1,4 & 1,7 & 1,9 & 2,2 & 2,4 & 3,6 \\
\hline & 100 & 1,5 & 1,7 & 2,1 & 2,4 & 2,7 & 3.0 & 4,4 \\
\hline & Контроль & 1,3 & 1,7 & 1.8 & 2,1 & 2,3 & 2,7 & 3.9 \\
\hline \multirow[t]{6}{*}{ E. coli 379} & 37 & 1,2 & 1,4 & 1.6 & 1.7 & 2.1 & 2.5 & 3.8 \\
\hline & Контроль & 1,2 & 1,4 & 1,6 & 1,8 & 2.1 & 2,3 & 3,4 \\
\hline & 70 & 1,6 & 1,9 & 2.2 & 2,6 & 2,7 & 2,9 & 4.3 \\
\hline & Контроль & 1,2 & 1,4 & 1,7 & 1,9 & 2,2 & 2,4 & 3,6 \\
\hline & 100 & 1,6 & 1,9 & 2,2 & 2,6 & 2,9 & 3.1 & 4,5 \\
\hline & Контроль & 1,3 & 1,7 & 1.8 & 2,1 & 2,3 & 2,7 & 3.9 \\
\hline
\end{tabular}

По данным, приведенным в таблице 2, гидрохинон в течение 10 ч вызывал задержку размножения всех исследуемых микроорганизмов.

При сравнении антимикробного эффекта арбутина и гидрохинона выявлены значительные различия их действия. Установлено, что наивысшие исследуемые дозы арбутина незначительно задерживают размножение стандартных штаммов E. coli 163 и Pr. mirabilis. Штаммы Klebsiela pneumonia и E. coli 137 оказались нечувствительными к растворам арбутина, т.е. антимикробная активность отсутствует. Интересно, что штамм E. coli 379, выделенный от больного хроническим циститом, вопреки ожидаемому эффекту, активно размножался в растворах арбутина, и к завершению эксперимента бактериальная концентрация в опытных пробирках превышала контрольную почти в 2 раза. Такая разница в эффектах арбутина на различные представители грамотрицательных микроорганизмов, очевидно, зависит от химического строения вещества. Арбутин является гликозидом и способен при воздействии некоторых бактериальных ферментов разлагаться до гидрохинона и глюкозы. В литературе приводятся сведения о выраженной антибактериальной активности гидрохинона [5]. Так, выделяясь при гидролизе арбутина, он, вероятно, и оказывал противомикробное действие на изучаемые штаммы E. coli 163 и Proteus mirabilis. Исследуемые штаммы Klebsiela pneumoniae и E. coli 137, вероятно, не выделяют ферментов, способных гидролизовать арбутин до гидрохинона, который мог бы оказать бактерицидный эффект. Однако штамм E. coli 379, выделенный от больного хроническим циститом, разлагает арбутин и активно использует выделившуюся при этом глюкозу в качестве дополнительного источника питания. Об этом свидетельствует не только увеличение скорости размножения данного штамма, но и выделение пузырьков газа и пены, которые образуются при разложении глюкозы в процессе обмена веществ микроорганизма до углекислого газа. Таким образом, арбутин, с одной стороны, может проявлять антимикробную активность за счет выделения гидрохинона, а с другой стороны, способствовать росту бактерий за счет выделения глюкозы. 
Исследование противомикробного эффекта гидрохинона показало высокую его активность в отношении всех изучаемых грамотрицательных микроорганизмов, что подтверждает данные литературы о антибактериальных свойствах этого вещества, в том числе и в отношении антибиотикорезистентных штаммов микроорганизмов [5]. Поскольку растворы гидрохинона останавливали рост и размножение не только стандартных, но и клинических штаммов. Такое действие гидрохинона также может быть обусловлено его структурой. Гидрохинон является фенолом и оказывает токсический эффект на живые клетки, в том числе и бактериальные [6]. Окисляясь, он превращается в бензохинон, который, в свою очередь, также может оказывать бактерицидное действие на микроорганизмы.

\section{Выводы}

1. Арбутин не обладает противомикробной активностью в отношении изучаемых штаммов, его действие на микроорганизмы реализуется при гидролизе, и в зависимости от условий может быть прямо противоположным: от антибактериального, за счет выделения гидрохинона, до способствующего росту бактерий, за счет выделения глюкозы.

2. Гидрохинон оказывает выраженное антибактериальное действие в отношении всех представленных штаммов грамотрицательных микроорганизмов.

\section{Список литературы}

1. Ботоева Е.А., Баханова Е.М. Антимикробная активность экстракта ортилии однобокой // Науки о человеке : матер. III конгресса молодых ученых и специалистов. Томск, 2002. С. 204-205.

2. Иванов В.В. Фармакотерапевтическая эффективность таблеток сухого экстракта толокнянки обыкновенной в комплексном лечении больных циститом : автореф. дис. ... канд. мед. наук. Улан-Удэ, 2004. 24 с.

3. Пензина Т.Н. Фармакологическая активность некоторых растений семейства Грушанковых : автореф. дис. ... канд. биол. наук . Барнаул, 1999. 24 с.

4. Siegers C. Bodinet C. Siegers CP. Bacterial deconjugation of arbutin by Escherichia coli // Phytomedicine. 2003. Vol. 10, no. 4. Pp. 58-60.

5. Куцик Р.В., Зузук Б.М., Недоступ А.Т., Пецк Т. Толокнянка обыкновенная // Провизор. 2003. №18. С. 11.

6. Todorovic V. Akutna trovanja fenolom // Medicinski Pregled. 2003. Vol. 56, no. 1. Pp. 37-41.

Поступило в редакцию 13 декабря 20112.

Voloboy N.L. , Butakova L.Yu., Smirnov I.V. STUDY OF ANTIMICROBIAL ARBUTIN AND HYDROQUINONE IN CERTAIN GRAM- FLORA OF REPRESENTATIVES

The Altay state medical university, pr. Lenina 40, Barnaul,(Russia), e-mail: voloboyn@gmail.com

Antimicrobic properties of many plants applied in urological practice, often connect with splitting of arbutin to of hydroquinone which actually and is an antiseptic tank. However, despite developed representation about action the plants containing of arbutin experimentally till now it is not established arbutin or hydroquinon the leading part in realization of antimicrobic effect belongs.

The purpose: compare antibacterial action of arbutin and hydroquinone concerning some gram-negative microorganisms.

Results: action of arbutin on microorganisms is realized at its hydrolysis, and depending on conditions can be antibacterial, at the expense of allocation hydroquinone, or to promote growth of bacteria, at the expense of glucose allocation. Hydroquinon has the expressed antibacterial an effect concerning all studied strain of gram-negative microorganisms.

Keywords: arbutin, hydrochinon, microorganisms, hydrolysis, antibacterial action.

\section{References}

1. Botoeva E.A., Bakhanova E.M. Nauki o cheloveke: mater. III kongressa molodykh uchenykh i spetsialistov [The human sciences: Materials III Congress of Young Scientists and Specialists]. Tomsk, 2002, pp. 204-205. (in Russ.).

2. Ivanov V.V. Farmakoterapevticheskaia effektivnost' tabletok sukhogo ekstrakta toloknianki obyknovennoi v kompleksnom lechenii bol'nykh tsistitom: avtoreferat dissertatsii kandidata meditsinskii nauk. [Pharmacotherapeutic efficacy of tablets dry extract of bearberry in the complex treatment of patients with cystitis: abstract of dissertation of the candidate of Medical Sciences]. Ulan-Ude, 2004, 24 p. (in Russ.).

3. Penzina T.N. Farmakologicheskaia aktivnost' nekotorykh rastenii semeistva Grushankovykh: avtoreferat dissertatsii kandidata biologicheskikh nauk. [The pharmacological activity of some plants of the family Grushankovyh: abstract of dissertation of the candidate of biological sciences]. Barnaul, 1999, 24 p. (in Russ.)

4. Siegers C. Bodinet C. Siegers C.P. Phytomedicine, 2003, vol. 10, no. 4, pp. 58-60.

5. Kutsik R.V., Zuzuk B.M., Nedostup A.T., Petsk T. Provizor, 2003, no. 18, pp. 11. (in Russ.).

6. Todorovic V. Medicinski Pregled., 2003, vol. 56, no. 1, pp. 37-41. (in Russ.).

\footnotetext{
* Corresponding author.
} 